\begin{tabular}{c}
\hline TÜRK \\
TARIM ve DOĞA BiLIMLERI \\
DERGISI \\
\hline \hline
\end{tabular}

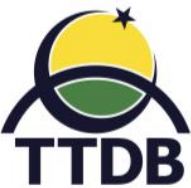

www.dergipark.gov.tr/turkjans

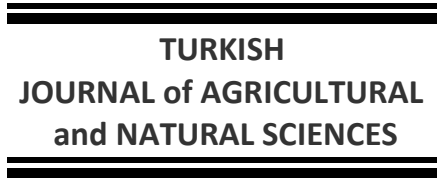

Araştırma Makalesi

\title{
Bolu Koşullarında Bazı Ekmeklik Buğday (Triticum aestivum L.) Çeşitlerinin Verim, Verim Unsurları ve Kalite Yönünden Değerlendirilmesi
}

\author{
Hüseyin GÜNGÖR ${ }^{1 *}$, Ziya DUMLUPINAR ${ }^{2}$ \\ ${ }^{1}$ Düzce Üniversitesi Ziraat ve Doğa Bilimleri Fakültesi Tarla Bitkileri Bölümü, Düzce \\ ${ }^{2}$ Kahramanmaraş Sütçü İmam Üniversitesi Ziraat Fakültesi Tarımsal Biyoteknoloji Bölümü, Kahramanmaraş
}

Sorumlu yazar: hgungor78@hotmail.com

Geliş Tarihi: 02.12.2018

Düzeltme Geliş Tarihi: 12.12 .2018

Kabul Tarihi: 15.01.2019

Özet

Bu çalışma, 18 ekmeklik buğday çeşidinin Bolu ekolojik koşullarında verim, verim unsurları ve kalite özelliklerinin belirlenmesi amacıyla 2016-2017 ve 2017-2018 vejetasyon dönemlerinde tesadüf blokları deneme desenine göre dört tekerrürlü olarak yürütülmüştür. Araştırmada çeşitlerin bitki boyu, başaklanma süresi, başak uzunluğu, başakta başakçık sayısı, başakta tane sayısı, başakta tane ağırlığı, bin tane ağırlığı, hektolitre ağırlığı, protein oranı, yaş gluten oranı ve tane verimi değerleri incelenmiştir. İncelenen tüm özellikler bakımından çeşitler arasında istatistiki olarak önemli farklılıklar elde edilmiştir. İki yılın ortalamasına göre çeşitlerin bitki boyları 80.7-112 cm, başaklanma süreleri 135.7-146.1 gün, başak uzunlukları 7.3-10 cm, başakta başakçık sayıları 16.5-21.2 adet, başakta tane sayıları 27.2-49.7 adet, başakta tane ağırlıkları 0.93-2.25 g, bin tane ağırlıkları 35.8-47.2 g, hektolitre ağırlıkları 69.3-80.9 kg, protein oranları \% 12.6-16.2, yaş gluten oranları \% 24.934.6 ve tane verimleri $515.2-790.7 \mathrm{~kg} / \mathrm{da}$ arasında değişmiştir. Elde edilen sonuçlara göre, en yüksek tane verimi Lucilla, Rumeli ve Aslı çeşitlerinden elde edilmiştir.

Anahtar kelimeler: Ekmeklik buğday, kalite özellikleri, tane verimi, verim unsurları.

\section{Evaluation of Some Bread Wheat (Triticum aestivum L.) Cultivars for Yield, Yield Components and Quality Traits in Bolu Conditions}

\begin{abstract}
This study was conducted during 2016-2017 and 2017-2018 under the ecological conditions of Bolu with the objective to determine the yield, yield components and quality traits of 18 bread wheat varieties. This study was done according to randomized complete block design with four replications. In this study, data was recorded on parameters of varieties such as plant height, heading time, spike length, number of spikelets per spike, number of grains per spike, grain weight per spike, 1000 kernel weight, hectoliter weight, protein content, wet gluten content, and grain yield. There was a statistically significant difference among the varieties based on the traits recorded. Two years average data indicated a plant height of $80.7-112 \mathrm{~cm}$, heading time of 135.7-146.1 days, spike length of 7.3-10.0 cm, number of spikelets per spike of 16.5-21.2, number of grains per spike of 27.2-49.7, grain weight per spike of 0.93-2.25 g, hectoliter weight of $69.3-80.9 \mathrm{~kg}$, protein contents of $12.6-16.2 \%$, wet gluten contents of $24.9-34.6 \%$, and grain yield of $515.2-790.7 \mathrm{~kg} / \mathrm{da}$. The highest yielding varieties were Lucilla, Rumeli and Aslı.
\end{abstract}

Key words: Bread wheat, grain yield, yield components, quality traits.

Giriş

Ülkemizde buğday 7.6 milyon hektar ekiliş alanı ve 20.6 milyon tonluk üretimi ile ilk sırada yer almaktadır. (Anonim, 2017). Türkiye'de buğday tarımı, büyük ölçüde kuru koşullarda yapıldığı için verim düşük ve dolayısıyla buğday üreticisinin geliri de diğer ürünleri yetiştiren üreticilere göre daha azdır (Kızılaslan, 2004). Ülke nüfusumuzun artışı 
karşısında gıda sorunlarını çözümlemedeki en önemli nokta tarım yapılan bölgeye uygun yüksek verim ve kaliteye sahip genotiplerin üretimlerinin yapılmasıdır. Özellikle son yıllarda araştırma enstitüleri ve yerli tohum firmalarının geliştirmiş oldukları çok sayıda ekmeklik buğday çeşidi bulunmaktadır. Bu ekmeklik buğday çeşitlerinden farklı ekolojik şartlara uygun yüksek verim ve kaliteye sahip olanların belirlenmesi ve üretimlerinin yaygınlaştırılması önem arz etmektedir. Ülkemizin farklı ekolojilere sahip bölgelerinde birçok araştırmacı tarafında çok sayıda araştırmalar yapılmıştır (Kurt ve Yağdı, 2013; Doğan ve ark., 2014; Sakin ve ark., 2015; Kara ve ark., 2016; Bayram ve ark., 2017; Mut ve ark., 2017; Tiryakioğlu ve ark., 2017; Erdoğan, 2018).

Ülkemizde buğday tarımı yapılan alanların farklı iklim ve toprak özelliklerine sahip olmalarından dolayı, çeşitli hastalıklar, zararlılar, kuraklık, tuzluluk gibi birçok stres faktörlerinin etkileri sonucu verim ve kalitede büyük oranda azalmalara neden olmaktadır. Bu olumsuz durumlar ise farklı özelliklere sahip yeni buğday çeşitlerinin üretime girmesiyle engellenebilir veya azaltılabilir (Doğan ve Kendal, 2013; Kızılgeçi ve ark., 2017).

Bu araştırmada, Bolu ekolojik koşullarında 18 ekmeklik buğday çeşidi tane verimi, verim unsurları ve bazı kalite özellikleri yönünden incelenerek, bölge koşullarına uygun yüksek verim ve kaliteli çeşitlerin belirlenmesi amacıyla 20162017 ve 2017-2018 yılları arasında yürütülmüştür.

\section{Materyal ve Yöntem}

Araştırma, 2016-2017 ve 2017-2018 yetiştiricilik dönemlerinde Bolu merkez çiftçi tarlasında yürütülmüştür. Denemenin yürütüldüğü Bolu ili $40^{\circ} 43^{\prime}$ kuzey paralelleri ve $31^{\circ} 37^{\prime}$ doğu meridyenleri arasında yer almakta olup, rakımı 742 m'dir. Çalışmada kullanılan çeşitlerle ilgili bilgiler Çizelge $\quad 1^{\prime}$ de verilmiştir.

Çizelge 1. Denemede kullanılan çeşitler, çeşit sahibi firma ve tescil tarihi.

\begin{tabular}{cllc}
\hline Sıra No & Çeşit Adı & Çeşit Sahibi Firma & Tescil Tarihi \\
\hline $\mathbf{1}$ & Lucilla & ProGen Tohum A.Ş. & 2017 \\
$\mathbf{2}$ & Masaccio & ProGen Tohum A.Ş. & 2014 \\
$\mathbf{3}$ & Midas & ProGen Tohum A.Ş. & 2014 \\
$\mathbf{4}$ & Aslı & ProGen Tohum A.Ş. & 2017 \\
$\mathbf{5}$ & Krasunia odes'ka & Marmara Tohum Geliştirme A.Ş. & 2008 \\
$\mathbf{6}$ & Rumeli & Trakya Tarım ve Vet. Tic.Ltd.Şti & 2012 \\
$\mathbf{7}$ & Pehlivan & Trakya T.A.E. & 1998 \\
$\mathbf{8}$ & Selimiye & Trakya T.A.E. & 2009 \\
$\mathbf{9}$ & Köprü & Trakya T.A.E. & 2015 \\
$\mathbf{1 0}$ & Saban & Trakya T.A.E. & 2014 \\
$\mathbf{1 1}$ & Bereket & Trakya T.A.E. & 2010 \\
$\mathbf{1 2}$ & Kate A-1 & Trakya T.A.E. & 1988 \\
$\mathbf{1 3}$ & Gelibolu & Trakya T.A.E. & 2005 \\
$\mathbf{1 4}$ & Aldane & Trakya T.A.E. & 2009 \\
$\mathbf{1 5}$ & Tekirdağ & Trakya T.A.E. & 2005 \\
$\mathbf{1 6}$ & Esperia & Tasaco A.Ş. & 2011 \\
$\mathbf{1 7}$ & Flamura 85 & Tareks A.Ş. & 1999 \\
$\mathbf{1 8}$ & Glosa & Tareks A.Ş. & 2014 \\
\hline
\end{tabular}

Denemenin yürütüldüğü üretim yıllarına ait meteorolojik veriler Çizelge 2'de verilmiştir (Anonim, 2018). Uzun yıllar ortalamasına göre yıllık yağış miktarı $453 \mathrm{~mm}$ olmuştur. Araştırmanın birinci yılında $365 \mathrm{~mm}$, ikinci yılında ise $570.1 \mathrm{~mm}$ yağış gerçekleşmiştir. Araştırmanın yapıldığı yıllar ve uzun yıllar ortalama sıcaklık sırasıyla $7.5,9.9$ ve $8.6{ }^{\circ} \mathrm{C}$ olarak tespit edilmiştir.

Araştırma tesadüf blokları deneme desenine göre 4 tekerrürlü olarak yürütülmüştür. Denemenin ekimleri birinci yıl için 10.11.2016, ikinci yıl için ise 14.11.2017 tarihlerinde yapılmıştır. Ekimler, 500 tane $/ \mathrm{m}^{2}$ bitki sıklığında, parsel alanı 5 $\mathrm{m}^{2}$ olacak şekilde elle yapılmıştır. Her iki yılda da aynı gübre formlarını kullanarak ekimle birlikte 6 $\mathrm{kg} / \mathrm{da}$ saf azot $(\mathrm{N})$ ve $6 \mathrm{~kg} / \mathrm{da}$ saf fosfor $\left(\mathrm{P}_{2} \mathrm{O}_{5}\right)$ olacak şekilde ekim öncesi gübreleme yapılırken, kardeşlenme döneminde ilave olarak $10 \mathrm{~kg} / \mathrm{da}$ saf azot (N) olacak şekilde üst gübreleme yapılmıştır. Yabancı ot mücadelesi kimyasal ilaçlarla yapılmıştır. Hasat, birinci yıl 23.07.2017, ikinci yıl ise 25.07.2018 tarihlerinde, elle yapılmıştır. 
Çizelge 2. Deneme yılları ve uzun yıllar ortalamasına ait bazı iklim verileri.

\begin{tabular}{|c|c|c|c|c|c|c|c|c|c|c|c|}
\hline \multirow{2}{*}{ Değerler } & \multirow{2}{*}{ Yillar } & \multicolumn{9}{|c|}{ Aylar } & \multirow{2}{*}{$\begin{array}{c}\text { Ortalama sıcaklık / } \\
\text { Toplam yağış }\end{array}$} \\
\hline & & 11 & 12 & 1 & 2 & 3 & 4 & 5 & 6 & 7 & \\
\hline \multirow{3}{*}{$\begin{array}{c}\text { Ortalama } \\
\left.\text { sıcaklık ( }{ }^{\circ} \mathrm{C}\right)\end{array}$} & 2016-2017 & 5.1 & -2.7 & -1.6 & 1.9 & 6.0 & 8.2 & 12.8 & 17.4 & 20.6 & 7.5 \\
\hline & 2017-2018 & 5.4 & 3.6 & 1.5 & 4.7 & 8.3 & 12.4 & 15.5 & 18.2 & 19.8 & 9.9 \\
\hline & Uzun Yıllar & 6.9 & 2.8 & 0.6 & 1.9 & 4.7 & 9.6 & 14.1 & 17.4 & 19.8 & 8.6 \\
\hline \multirow{3}{*}{ Yağış (mm) } & $2016-2017$ & 29.9 & 49.6 & 29.5 & 19.9 & 31.9 & 63.7 & 74.1 & 64.8 & 1.6 & 365 \\
\hline & 2017-2018 & 58.4 & 66.8 & 46.1 & 29.6 & 102.4 & 18.7 & 99.8 & 111.2 & 37.1 & 570.1 \\
\hline & Uzun Yıllar & 45.1 & 59.5 & 57.7 & 48.3 & 49.9 & 51.1 & 59.1 & 54.6 & 27.7 & 453 \\
\hline \multirow{2}{*}{ Nisbi nem (\%) } & 2016-2017 & 72.9 & 86.6 & 76.1 & 73.5 & 68.4 & 66.1 & 74.7 & 73.3 & 65.8 & 73 \\
\hline & 2017-2018 & 80.9 & 81.9 & 81.5 & 79 & 70,9 & 63.3 & 76.4 & 73.1 & 71.2 & 75.4 \\
\hline
\end{tabular}

Araştırmada bitki boyu, başaklanma süresi (Ocak ayından itibaren bitkilerin her parselde \%50 oranında başaklandığı güne kadar geçen gün sayısı), başak uzunluğu, başakta başakçık sayısı, başakta tane sayısı, başakta tane ağırlığı, bin tane ağırlığı, hektolitre ağırlığı, protein oranı (NIR), yaş gluten oranı (NIR) ve tane verim'ine ait veriler değerlendirilmiştir.

Araştırmada elde edilen sonuçlar JMP 10 istatistik analiz programında yapılmış (JMP, 2010), farklılık belirlenen özelliklerin ortalamaları arasındaki karşılaştırmalar ise Duncan çoklu karşılaştırma testi ile değerlendirilmiştir.

\section{Bulgular ve Tartışma}

Denemeye alınan çeşitlerin bitki boyuna ilişkin ortalama değerler Çizelge 3'de verilmiştir. Çalışmada bitki boyu bakımından çeşitler arasındaki farkın istatistiksel olarak önemli olduğu saptanmıştır. Çalışmanın birinci yılında bitki boyu 91.0-127.5 cm, ikinci yılında 70.2-97.2 cm ve yılların ortalamasına göre ise $80.7-112.0 \mathrm{~cm}$ arasında değişmiştir. En uzun bitki boyu Midas, en kısa bitki boyu ise Esperia çeşidinden tespit edilmiştir. Yıllara göre bitki boyu farklı bulunmuştur. Birinci yıl ortalama $106.2 \mathrm{~cm}$, ikinci yıl $83.3 \mathrm{~cm}$ ve iki yılın ortalamasına göre ise bitki boyu $94.7 \mathrm{~cm}$ olarak saptanmıştır. Buğdayda bitki boyunun genotipik yapıya, iklim ve toprak şartlarına ve aynı zamanda da yetiştiricilik koşullarına göre değiştiği farklı bölgelerde yapılan çalışmalarda bildirilmiştir (Doğan ve ark., 2014; Sakin ve ark., 2015; Kara ve ark., 2016; Mut ve ark., 2017).

Araştırmada, ekmeklik buğday çeşitlerinin başaklanma süreleri arasındaki farklılıklar her iki yılda da önemli bulunmuştur. Çalışmanın birinci yılı, ikinci yılı ve iki yıllık ortalama değerlere göre en kısa başaklanma süresi Tekirdağ çeşidinden (sırasıyla, 141.0, 130.5, 135.7 gün) tespit edilirken en uzun başaklanma süresi ise Midas çeşidinden (sırasıyla, 151.5, 140.7, 146.1 gün) tespit edilmiştir. Birinci yıl ortalama başaklanma süresi 141.0 gün, ikinci yıl ortalama başaklanma süresi 132.6 gün ve iki yılın ortalamasına göre ise 138.4 gün olarak tespit edilmiştir (Çizelge 3). Farklı bölge koşullarında yapılan araştırmalarda başaklanma süresi bakımından önemli farklılıklar olduğu tespit edilmiş olup, bu durumun oluşmasında genotip ve çevrenin birlikte etkili olduğu bildirilmektedir (Doğan ve Kendal, 2012; Sakin ve ark., 2017).

Çizelge 3 incelendiğinde çalışmanın birinci yılı çeşitlerin başak uzunluğu değerleri $7.1-9.7 \mathrm{~cm}$ arasında değişmiştir. Başak uzunluğu en fazla Krasunia odes'ka ve Kate A1 çeşitleri olurken, en kısa başak uzunluğuna ise Midas çeşidi sahip olmuştur. İkinci yıl başak uzunlukları 7.4-10.2 cm arasında değişmiştir. Başak uzunluğu en fazla Krasunia odes'ka, en kısa ise Midas çeşidinden ölçülmüştür. İki yılın birleştirilmiş ortalaması $8.5 \mathrm{~cm}$ olarak tespit edilmiştir. İki yılın ortalamasına göre en uzun başak boyu $10.0 \mathrm{~cm}$ ile Krasunia odes'ka çeşidinden, en kısa başak boyu ise $7.3 \mathrm{~cm}$ ile Midas çeşidinden ölçülmüştür. Yapılan diğer çalışmalarda, Kurt ve Yağdı (2013) $8.3 \mathrm{~cm}$, Kara ve ark., (2016) 7.91-8.87 cm, Sakin ve ark., (2017) $9.1-9.2 \mathrm{~cm}$ değerlerinde başak uzunlukları elde etmişlerdir.

Başakta başakçık sayısı açısından birinci yıl çeşitler 16.2-20.7 adet arasında değişen değerler almıştır. Başakçık sayısı en fazla olan çeşit 20.7 adet ile Krasunia odes'ka olurken başakçık sayısı en az olan çeşit 16.2 adet ile Masaccio olmuştur. İkinci yıl başakçık sayısı değerleri 16.2-21.7 adet arasında değerler almıştır. Yılların ortalamasına göre başakçık sayısı 16.5-21.2 adet arasında değişirken ortalama 18.1 adet olarak saptanmıştır. Birleştirilmiş yıl değerlerine göre başakçık sayısı en fazla olan çeşit 21.2 adet ile Krasunia odes'ka olurken başakçık sayısı en az olan ise 16.5 adet ile Aldane, Masaccio ve Flamura-85 çeşitlerinden saptanmıştır. Yapılan benzer çalışmalarda başakta başakçık sayısını; Kurt ve Yağdı (2013), 17.3-19.5 adet; Güçlü (2015), 17.43-18.80 adet; Erdoğan (2018), 17.5-20.2 adet olarak bildirmişlerdir. 
Çizelge 3. Ekmeklik buğday çeșitlerinde bitki boyu, başaklanma süresi, başak uzunluğu ve başakta başakçık sayısı değerleri.

\begin{tabular}{|c|c|c|c|c|c|c|c|c|c|c|c|c|}
\hline \multirow[b]{2}{*}{ Çeşitler } & \multicolumn{3}{|c|}{ Bitki boyu (cm) } & \multicolumn{3}{|c|}{ Başaklanma süresi (gün) } & \multicolumn{3}{|c|}{ Başak uzunluğu (cm) } & \multicolumn{3}{|c|}{ Başakta başakçık sayısı (adet) } \\
\hline & 2016-17 & 2017-18 & $\begin{array}{c}\text { Birleşik } \\
\text { yıllar }\end{array}$ & 2016-17 & 2017-18 & $\begin{array}{c}\text { Birleşik } \\
\text { yıllar }\end{array}$ & 2016-17 & 2017-18 & $\begin{array}{c}\text { Birleşik } \\
\text { yıllar }\end{array}$ & 2016-17 & 2017-18 & $\begin{array}{c}\text { Birleşik } \\
\text { yıllar }\end{array}$ \\
\hline Lucilla & 108.7 def & $92.2 \mathrm{~b}$ & $100.5 d$ & $143.2 \mathrm{fgh}$ & $131.2 \mathrm{~g}-\mathrm{j}$ & $137.2 \mathrm{e}$ & $9.5 \mathrm{ab}$ & $9.1 \mathrm{bc}$ & $9.3 \mathrm{bc}$ & 18.2 b-e & 17.5 def & $17.9 \mathrm{~d}-\mathrm{g}$ \\
\hline Midas & $127.5 \mathrm{a}$ & 96.5 a & $112.0 \mathrm{a}$ & $151.5 \mathrm{a}$ & 140.7 a & $146.1 \mathrm{a}$ & $7.1 \mathrm{f}$ & $7.4 \mathrm{~g}$ & $7.3 \mathrm{~g}$ & $18.5 \mathrm{bcd}$ & $18.0 \mathrm{c}-\mathrm{f}$ & $18.2 c-f$ \\
\hline Aslı & $114.2 \mathrm{~b}$ & $94.2 \mathrm{ab}$ & $104.2 \mathrm{~b}$ & $148.0 \mathrm{~b}$ & $136.7 \mathrm{~b}$ & $142.4 \mathrm{~b}$ & 7.6 ef & 7.9 efg & $7.7 \mathrm{fg}$ & 16.5 ef & 17.5 def & $17.0 \mathrm{fgh}$ \\
\hline Krasunia odes'ka & $105.8 \mathrm{f}-\mathrm{I}$ & $84.7 \mathrm{~cd}$ & $95.2 \mathrm{e}$ & $143.0 \mathrm{gh}$ & $131.7 \mathrm{f}-\mathrm{I}$ & $137.4 \mathrm{e}$ & $9.7 \mathrm{a}$ & $10.2 \mathrm{a}$ & $10.0 \mathrm{a}$ & 20.7 a & $21.7 \mathrm{a}$ & $21.2 \mathrm{a}$ \\
\hline Rumeli & 107.0 e-h & $74.3 \mathrm{fg}$ & $90.6 \mathrm{fg}$ & $142.2 \mathrm{gh}$ & 131.0 hij & 136,6 ef & $8.5 \mathrm{~cd}$ & $9.1 \mathrm{bc}$ & $8.8 \mathrm{~cd}$ & 18.7 bc & $20.5 a b$ & 19.6 b \\
\hline Esperia & 91.01 & $70.5 \mathrm{~h}$ & $80.7 \mathrm{j}$ & $142.5 \mathrm{ghı}$ & 132.0 e-h & $137.2 \mathrm{e}$ & $8.2 \mathrm{cde}$ & $8.2 \mathrm{def}$ & 8.2 ef & $18.0 b-f$ & $18.7 \mathrm{bcd}$ & $18.4 \mathrm{~b}-\mathrm{e}$ \\
\hline Pehlivan & 110.0 cde & $97.2 \mathrm{a}$ & 103.6 bc & 145.7 c & $133.0 \mathrm{de}$ & $139.4 \mathrm{~cd}$ & $9.0 \mathrm{abc}$ & $8.6 \mathrm{cde}$ & $8.8 \mathrm{~cd}$ & $18.5 \mathrm{bcd}$ & 18.2 cde & $18.4 \mathrm{~b}-\mathrm{e}$ \\
\hline Selimiye & $104.7 \mathrm{ghı}$ & $84.2 \mathrm{~cd}$ & 94.5 e & 145.0 cde & 132.7 def & $138.9 \mathrm{~d}$ & $9.0 \mathrm{abc}$ & $8.3 \mathrm{def}$ & $8.7 \mathrm{de}$ & $17.2 \mathrm{c}-\mathrm{f}$ & 16.5 ef & $16.9 \mathrm{gh}$ \\
\hline Köprü & $106.0 \mathrm{f}$ - & $87.0 \mathrm{c}$ & 96.5 e & 146.2 c & $134.5 \mathrm{c}$ & $140.4 \mathrm{c}$ & $8.10 \mathrm{de}$ & $8.2 \mathrm{def}$ & 8.2 ef & $19.5 a b$ & $19.5 \mathrm{bc}$ & $19.5 \mathrm{bc}$ \\
\hline Saban & $100.0 \mathrm{jk}$ & $75.0 \mathrm{f}$ & $87.5 \mathrm{~h}$ & $142.7 \mathrm{gh}$ & زا 130.7 & $136.7 \mathrm{ef}$ & $8.0 \mathrm{de}$ & $8.3 \mathrm{def}$ & 8.1 ef & $17.0 \mathrm{c}-\mathrm{f}$ & 17.5 def & $17.2 \mathrm{e}-\mathrm{h}$ \\
\hline Flamura-85 & 103.5 hıj & 80.3 e & $91.9 \mathrm{f}$ & $144.7 \mathrm{c}-\mathrm{f}$ & $132.2 \mathrm{efg}$ & $138.5 \mathrm{~d}$ & $8.7 \mathrm{bcd}$ & $8.4 c-f$ & $8.6 \mathrm{de}$ & 16.5 ef & 16.5 ef & $16.5 \mathrm{~h}$ \\
\hline Bereket & $111.0 \mathrm{bcd}$ & $92.7 \mathrm{~b}$ & $101.9 \mathrm{~cd}$ & $143.7 \mathrm{~d}-\mathrm{g}$ & 131.0 hij & $137.4 \mathrm{e}$ & $8.6 \mathrm{~cd}$ & 9.1 bc & $8.9 \mathrm{~cd}$ & 18.7 bc & $19.0 \mathrm{bcd}$ & $18.9 \mathrm{bcd}$ \\
\hline Glosa & 102.5 ijk & $75.5 \mathrm{f}$ & $89.0 \mathrm{gh}$ & $142.5 \mathrm{ghı}$ & 130.7 i & 136.6 ef & 7.7 ef & 7.9 efg & $7.8 \mathrm{f}$ & $17.5 c-f$ & $18.0 \mathrm{c}-\mathrm{f}$ & $17.7 d-h$ \\
\hline Masaccio & $99.0 \mathrm{k}$ & $70.2 \mathrm{~h}$ & 84.61 & $142.0 \mathrm{hl}$ & $131.2 \mathrm{~g}-\mathrm{j}$ & $136.6 \mathrm{ef}$ & 7.5 ef & $8.1 \mathrm{def}$ & $7.8 \mathrm{f}$ & $16.2 \mathrm{f}$ & 16.7 ef & $16.5 \mathrm{~h}$ \\
\hline Kate A1 & $113.0 \mathrm{bc}$ & $95.2 \mathrm{ab}$ & 104.1 bc & $145.2 \mathrm{~cd}$ & $133.7 \mathrm{~cd}$ & $139.5 \mathrm{~cd}$ & $9.7 \mathrm{a}$ & $9.6 a b$ & $9.6 \mathrm{ab}$ & $17.7 b-f$ & $18.0 \mathrm{c}-\mathrm{f}$ & $17.9 \mathrm{~d}-\mathrm{g}$ \\
\hline Gelibolu & $105.5 \mathrm{f}$ & $75.5 \mathrm{f}$ & $90.5 \mathrm{fg}$ & $142.5 \mathrm{ghı}$ & 131.0 hij & 136.7 ef & 8.2 cde & $7.8 \mathrm{fg}$ & $8.0 \mathrm{f}$ & $18.0 \mathrm{~b}-\mathrm{f}$ & $17.2 \mathrm{def}$ & $17.6 \mathrm{~d}-\mathrm{h}$ \\
\hline Aldane & 107.2 efg & $82.2 \mathrm{de}$ & 94.7 e & 143.5 e-h & $131.2 \mathrm{~g}-\mathrm{j}$ & $137.4 \mathrm{e}$ & $8.8 \mathrm{bcd}$ & $8.8 \mathrm{~cd}$ & $8.8 \mathrm{~cd}$ & 16.7 def & $16.2 \mathrm{f}$ & $16.5 \mathrm{~h}$ \\
\hline Tekirdağ & 93.71 & $71.5 \mathrm{gh}$ & 82.6 i & I41.0 I & $130.5 \mathrm{j}$ & $135.7 \mathrm{f}$ & $8.9 a b c$ & $9.7 a b$ & $9.3 \mathrm{bc}$ & 18.7 bc & 19.7 bc & 19.2 bc \\
\hline Ortalama & $106.2 \mathrm{a}$ & $83.3 \mathrm{~b}$ & 94.7 & $144.2 \mathrm{a}$ & $132.6 \mathrm{~b}$ & 138.4 & 8.5 & 8.6 & 8.5 & 18.0 & 18.2 & 18.1 \\
\hline D.K. & $2.41 * *$ & $2.57 * *$ & $2.49 * *$ & $0.84 * *$ & $0.61^{* *}$ & $0.74^{* *}$ & $6.79 * *$ & $5.91 * *$ & $6.36 * *$ & $7.30 * *$ & $7.06^{* *}$ & $7.18^{* *}$ \\
\hline
\end{tabular}

**,* Sırasıyla 0.01 ve 0.05 düzeyinde önemlidir. Aynı harfle gösterilen değerler 0.05 önem düzeyinde farklı değildir. 
Çizelge 4. Ekmeklik buğday çeşitlerinde başakta tane sayısı, başakta tane ağırlığı, bin tane ağırlığı ve hektolitre ağırlığı değerleri.

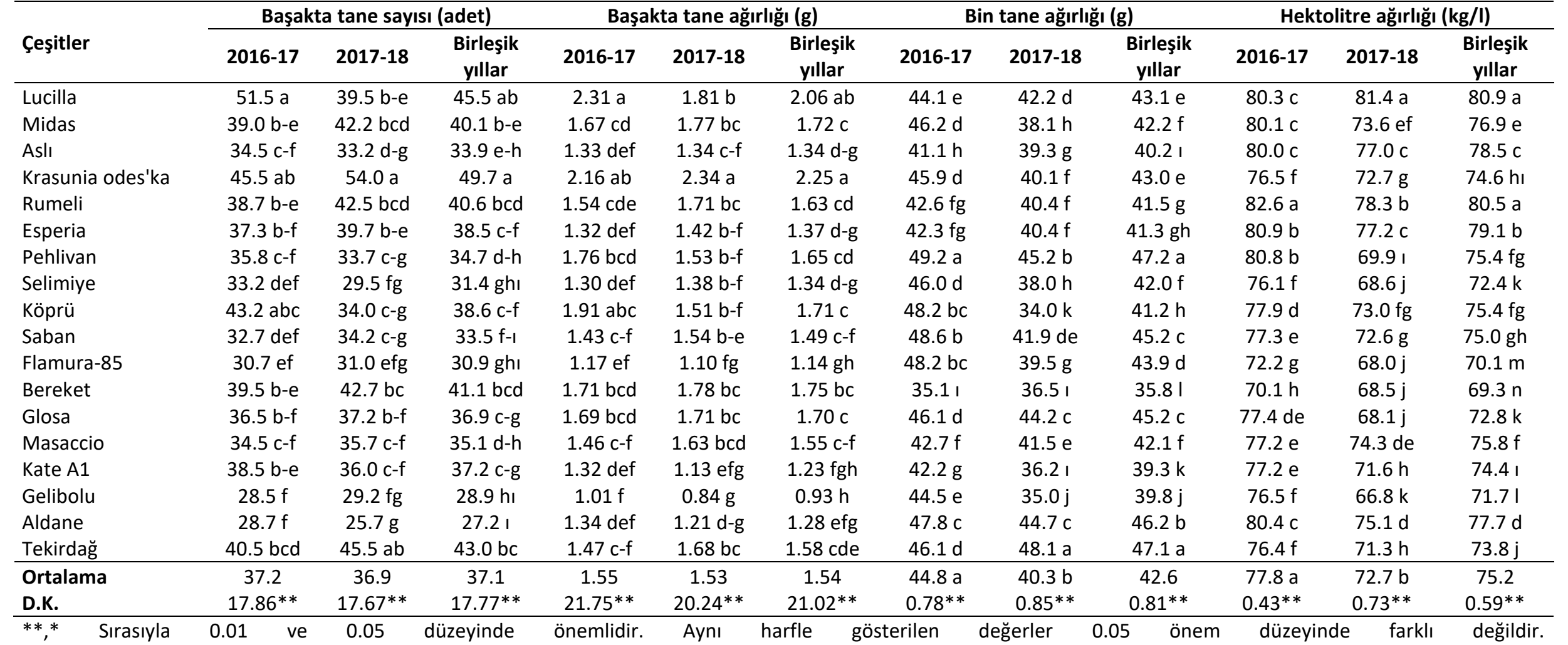


Başakta tane sayısı açısından yıllar önemsiz, çeşitler ise her iki yılda ve ortalamaya göre istatistiki olarak \%1 düzeyinde önemli olmuştur (Çizelge 4). Başakta tane sayısı birinci yıl 28.5-51.5 adet, ikinci yıl 25.7-54.0 adet ve yılların ortalamalarına göre ise 27.2-49.7adet olarak tespit edilmiştir. Çalışmanın birinci yılı, ikinci yılı ve yılların ortalamasına göre başakta tane sayısı en fazla olan çeşitler Lucilla ve Krasunia odes'ka olarak belirlenmiştir. Başakta tane sayısı sapa kalkma ve çiçeklenme dönemleri arasında belirlendiğinden (Kirby, 1988) denemenin ikinci yılı sapa kalkma dönemi yağış miktarının düşük olarak gerçekleşmesi birinci yıla göre başakta tane sayısında bazı çeşitlerde bir miktar azalmaya sebep olmuştur (Çizelge 4). Bu araştırmanın sonuçlarına benzer şekilde diğer araştırıcılar da başata tane sayısının çeşitlere göre değiştiğini belirlemişlerdir (Güçlü, 2015; Kara ve ark., 2016; Bayram ve ark., 2017; Erdoğan, 2018).

Denemeye alınan çeşitlerin başak tane ağırlığına ait ortalama değerler Çizelge 4'te verilmiştir. Başak tane ağırlığı açısından çeşitler arasındaki fark önemli olurken yıllar arasında istatistiki olarak fark önemli olmamıştır. Çeşitlerin ortalaması olarak başak tane ağırlığı birinci yıl 1.55 $\mathrm{g}$, ikinci yıl ise $1.53 \mathrm{~g}$ olmuştur. Çeşitlerin başak tane ağırlıkları birinci yıl 1.01-2.31 g, ikinci yıl ise 0.84-2.34 g arasında değişirken iki yılın ortalamasına göre 0.93-2.25 g arasında değişmiştir. Başak tane ağırlığı birinci yıl, ikinci yıl ve iki yılın ortalamasına göre en fazla Lucilla ve Krasunia odes'ka çeşitlerinden, en düşük değer ise Gelibolu çeşidinden elde edilmiştir. Yapılan benzer çalışmalarda başak tane ağırlığını; Kurt ve Yağdı (2013), 1.7 g; Güçlü (2015), 1.06-1.57 g; Kara ve ark., (2016), 1.425-1.966 g; Erdoğan (2018), 2.2-3.8 g olarak bildirmişlerdir.

Bin tane ağırlığı yönünden buğday çeşitleri, yıllar ve yılxçeşit interaksiyonu arasındaki farklar önemli bulunmuştur. Çeşitlerin bin tane ağırlıkları çalışmanın birinci yılında 35.1 ile $49.2 \mathrm{~g}$, ikinci yılında 34.0 ile $48.1 \mathrm{~g}$, yılların ortalaması olarak ise 35.8 ile $47.2 \mathrm{~g}$ arasında değişim göstermiş, ortalama değer ise $42.6 \mathrm{~g}$ olarak tespit edilmiştir. Buğdayın tane ağılığı ve verim unsurları çiçeklenme sonrası gelişme süreçleri ve çevre koşulları tarafından belirlenir (Wiegand ve ark., 1981). Yıllar arasında fark oluşması, çiçeklenme sonrası dönemdeki ılıman ve yağışlı hava koşulları nedeniyle, 2017-2018 vejetasyon yılında mantari hastalıların enfeksiyonuna neden olarak çeşitlerin çoğunluğunda bin tane ağırlığını önemli derecede azaltmıştır. Yapılan benzer çalışmalarda bin tane ağırlığını; Kara ve ark., (2016), 37.3-43.7 g; Aydoğan ve Soylu (2017), 30.90-46.46 g; Aktaş ve ark., (2017), 26.79-30.94 g olarak bildirmişlerdir.
Hektolitre ağırlığı çeşitlerde araştırmanın iki yılında da istatistiki olarak önemli bulunmuştur. Çizelge 4'de görüldüğü gibi hektolitre ağırlığı birinci yıl $77.8 \mathrm{~kg}$ ve ikinci yıl ise $72.7 \mathrm{~kg}$ olarak bulunmuştur. Yılların ortalamasına göre çeşitlerin ortalama hektolitre ağırlığı 69.3-80.9 kg arasında değişirken, en yüksek hektolitre ağırlığı Lucilla (80.9 $\mathrm{kg})$ ve Rumeli $(80.5 \mathrm{~kg}$ ) çeşitlerinde ölçülmüştür. Hektolitre ağırlığı çeşit, çevre şartları, kültürel uygulamalar gibi farklı stres koşullarından önemli derece etkilenebilmektedir. Yapılan benzer çalışmalarda hektolitre ağırlığını, Kendal (2013) 77$82 \mathrm{~kg}$, Kara ve ark., (2016) 74.9-79.2 kg, Mut ve ark., (2017) 77.6-79.7 kg olarak tespit etmişlerdir.

Protein oranı için yapılan istatistik analizine göre çeşitler, yıl ve yılxçeşit interaksiyonu \%1 düzeyinde önemli bulunmuştur (Çizelge 5). Protein oranı birinci yıl \%13.7 ve ikinci yıl ise \%14.4 olarak bulunmuştur. Yılların ortalamasına göre çeşitlerin ortalama Protein oranı \%12.6-16.2 arasında değişirken, en yüksek protein oranı Rumeli (\%16.2) ve Aldane (\%15.7) çeşitlerinde ölçülmüştür. Protein oranı, çeşit, çevre şartları, kültürel uygulamalar, iklim faktörleri, hastalık ve zararlılar gibi farklı koşullardan önemli derece etkilenebilmektedir. Yapılan benzer çalışmalarda protein oranı, Kendal (2013) \%9.8-11.2, Aydoğan ve Soylu (2017) \%11.93-13.44, Mut ve ark., (2017) \%12.0-13.8 olarak tespit etmişlerdir.

Araştırmada, ekmeklik buğday çeşitlerinin gluten oranları açısından çeşit, yıl ve yılxçeşit interaksiyonu \%1 düzeyinde önemli bulunmuştur. Çalışmanın birinci yılı, ikinci yılı ve iki yıllık ortalama değerlere göre en düşük gluten oranı Bereket çeşidinden (\%25.2, \%24.6, \%24.9) tespit edilirken en fazla gluten oranı ise Rumeli çeşidinden (\%31.3, \%37.9, \%34.6) tespit edilmiştir. Birinci yıl ortalama gluten oranı \%28.0, ikinci yıl ortalama gluten oranı \%29.6 ve iki yılın ortalamasına göre ise \%28.8 olarak tespit edilmiştir (Çizelge 5). Ekmeklik veya diğer unlarda kalitenin en önemli unsurlarından biri gluten oranıdır. Farklı bölge koşullarında yapılan çalışmalarda, Özen ve Akman (2015), \%23.2; Mut ve ark., (2017), \%24.1-26.3; olarak tespit etmişlerdir.

Tane verimi yönünden yıllar, çeşit ve yılxçeşit interaksiyonu arasında istatistiki olarak fark önemli olmuştur (Çizelge 5). Çeşitlerin tane verimleri birinci yıl 523.5-844.4 kg/da, ikinci yıl 486.2-737.1 kg/da arasında değişirken ortalama tane verimi ise $606.7 \mathrm{~kg} / \mathrm{da}$ olarak tespit edilmiştir. Birinci yıl en yüksek tane verimi Lucilla, ikinci yıl ise Lucilla, Aslı, Rumeli çeşitlerinden elde edilmiştir. Yılların ortalamalarına göre en yüksek tane verimi Lucilla çeşidinden elde edilmiştir. Denemenin birinci yılında ortalama ve çeşitlerin genelinde tane verimleri ikinci yıldan daha yüksek olarak tespit 
edilmiştir. Bunun nedeni denemin ikinci yılında nisan ayının kurak geçmesi, Mayıs ve Haziran aylarının aşırı yağışlı geçmesi tane verimlerinde düşüşe neden olmuştur (Çizelge 2). Tane verimi genotipin genetik potansiyeli, çevre şartları ve yetiştiricilik koşullarına göre değişmektedir. Farklı bölgelerde benzer yapılan çalışmalarda tane veriminin genotiplere göre değiştiği diğer araştırmacılar tarafından da belirlenmiştir (Aktaş ve ark., 2017; Aydoğan ve Soylu, 2017; Mut ve ark., 2017; Erdoğan, 2018).

Çizelge 5. Ekmeklik buğday çeşitlerinde protein oranı, gluten oranı ve tane verimi değerleri.

\begin{tabular}{|c|c|c|c|c|c|c|c|c|c|}
\hline \multirow[b]{2}{*}{ Çeşitler } & \multicolumn{3}{|c|}{ Protein oranı (\%) } & \multicolumn{3}{|c|}{ Gluten oranı (\%) } & \multicolumn{3}{|c|}{ Tane verimi (kg/da) } \\
\hline & 2016-17 & 2017-18 & $\begin{array}{c}\text { Birleşik } \\
\text { yıllar }\end{array}$ & 2016-17 & 2017-18 & $\begin{array}{c}\text { Birleşik } \\
\text { yıllar }\end{array}$ & 2016-17 & 2017-18 & $\begin{array}{c}\text { Birleşik } \\
\text { yıllar }\end{array}$ \\
\hline Lucilla & 13.2 I & $13.6 \mathrm{~g}$ & $13.4 \mathrm{~g}$ & $26.6 \mathrm{jk}$ & $28.3 \mathrm{j}$ & $27.5 \mathrm{jk}$ & $844.4 \mathrm{a}$ & $737.1 \mathrm{a}$ & $790.7 \mathrm{a}$ \\
\hline Midas & $14.2 \mathrm{f}$ & $15.2 \mathrm{~d}$ & $14.7 \mathrm{e}$ & $29.2 \mathrm{e}$ & $32.2 \mathrm{~d}$ & $30.7 \mathrm{e}$ & $714.0 \mathrm{c}$ & 535.2 ef & $624.6 \mathrm{c}$ \\
\hline Aslı & $13.4 \mathrm{~h}$ & 14.4 ef & $13.9 \mathrm{f}$ & $26.7 \mathrm{j}$ & $29.5 \mathrm{~h}$ & 28.1 I & $701.2 \mathrm{c}$ & $699.2 \mathrm{a}$ & $700.2 b$ \\
\hline Krasunia odes'ka & 13.2 । & $13.9 \mathrm{~g}$ & $13.5 \mathrm{~g}$ & $26.8 \mathrm{j}$ & $28.1 \mathrm{jk}$ & $27.5 \mathrm{j}$ & 670.8 cde & $600.1 \mathrm{bcd}$ & $635.5 c$ \\
\hline Rumeli & $15.2 \mathrm{a}$ & $17.1 \mathrm{a}$ & $16.2 \mathrm{a}$ & $31.3 \mathrm{a}$ & $37.9 \mathrm{a}$ & $34.6 \mathrm{a}$ & $772.6 b$ & $703.0 \mathrm{a}$ & $737.8 \mathrm{~b}$ \\
\hline Esperia & $14.9 \mathrm{c}$ & $15.9 \mathrm{bc}$ & $15.4 \mathrm{c}$ & $30.5 c$ & $33.2 \mathrm{c}$ & $31.9 c$ & $523.5 \mathrm{~h}$ & $546.7 c-f$ & 535.1 ef \\
\hline Pehlivan & 13.2 । & $13.8 \mathrm{~g}$ & $13.5 \mathrm{~g}$ & $26.5 \mathrm{kl}$ & $28.0 \mathrm{k}$ & 27.21 & $715.0 \mathrm{c}$ & 537.4 ef & $626.2 \mathrm{c}$ \\
\hline Selimiye & $12.9 \mathrm{j}$ & $13.0 \mathrm{~h}$ & $12.9 \mathrm{~h}$ & $26.4 \mathrm{kl}$ & $25.2 \mathrm{~m}$ & $25.8 n$ & $614.1 \mathrm{fg}$ & $506.8 \mathrm{f}$ & $560.5 \mathrm{e}$ \\
\hline Köprü & $12.8 \mathrm{j}$ & $14.3 \mathrm{f}$ & $13.6 \mathrm{~g}$ & $25.4 \mathrm{~m}$ & 29.2 I & $27.3 \mathrm{kl}$ & $573.0 \mathrm{gh}$ & $497.0 \mathrm{f}$ & 535.0 ef \\
\hline Saban & $13.5 \mathrm{~h}$ & $14.7 \mathrm{e}$ & $14.1 \mathrm{f}$ & $27.5 \mathrm{~h}$ & $30.4 \mathrm{f}$ & $28.9 \mathrm{~h}$ & 634.2 ef & 580.2 b-e & $607.2 \mathrm{~cd}$ \\
\hline Flamura-85 & $14.7 \mathrm{~d}$ & 14.5 ef & $14.7 \mathrm{e}$ & $30.6 \mathrm{c}$ & $30.0 \mathrm{~g}$ & $30.3 \mathrm{f}$ & $543.1 \mathrm{~h}$ & 541.3 def & 542.2 ef \\
\hline Bereket & $12.5 \mathrm{k}$ & $12.7 \mathrm{hl}$ & $12.6 \mathrm{I}$ & $25.2 n$ & $24.6 n$ & 24.9 o & $617.0 \mathrm{fg}$ & $486.2 \mathrm{f}$ & 551.6 ef \\
\hline Glosa & $13.8 \mathrm{~g}$ & $15.2 \mathrm{~d}$ & $14.5 \mathrm{e}$ & $27.8 \mathrm{~g}$ & $31.4 \mathrm{e}$ & $29.7 \mathrm{~g}$ & $527.3 \mathrm{~h}$ & $614.8 b$ & $571.0 \mathrm{de}$ \\
\hline Masaccio & $12.9 \mathrm{j}$ & $12.9 \mathrm{hl}$ & $12.9 \mathrm{~h}$ & 26.31 & $27.9 \mathrm{k}$ & 27.21 & $698.2 \mathrm{~cd}$ & 589.3 b-e & $643.8 \mathrm{c}$ \\
\hline Kate A1 & $13.8 \mathrm{~g}$ & $12.2 \mathrm{j}$ & $13.0 \mathrm{~h}$ & $28.4 \mathrm{f}$ & 24.00 & $26.2 \mathrm{~m}$ & 647.7 def & 607.8 bc & $627.7 \mathrm{c}$ \\
\hline Gelibolu & 13.2 I & $12.6 \mathrm{j}$ & $12.9 \mathrm{~h}$ & 27.11 & 25.51 & $26.3 \mathrm{~m}$ & $612.9 \mathrm{fg}$ & $516.4 \mathrm{f}$ & $564.7 \mathrm{e}$ \\
\hline Aldane & $15.0 \mathrm{~b}$ & $16.3 \mathrm{~b}$ & $15.7 \mathrm{~b}$ & $31.1 \mathrm{~b}$ & $33.9 \mathrm{~b}$ & $32.5 \mathrm{~b}$ & $525.6 \mathrm{~h}$ & $504.8 \mathrm{f}$ & $515.2 \mathrm{f}$ \\
\hline Tekirdağ & $14.4 \mathrm{e}$ & $15.8 \mathrm{c}$ & $15.1 \mathrm{~d}$ & $29.6 \mathrm{~d}$ & $33.3 \mathrm{c}$ & $31.5 \mathrm{~d}$ & $570.9 \mathrm{gh}$ & 530.7 ef & 550.8 ef \\
\hline Ortalama & $13.7 \mathrm{~b}$ & $14.4 \mathrm{a}$ & 14.0 & $28.0 \mathrm{~b}$ & $29.6 \mathrm{a}$ & 28.8 & $639.2 \mathrm{a}$ & $574.1 \mathrm{~b}$ & 606.7 \\
\hline D.K. & $0.71 * *$ & $1.83 * *$ & $1.41^{* *}$ & $0.44 * *$ & $0.65 * *$ & $0.56^{* *}$ & $5.80 * *$ & $7.51^{* *}$ & $6.79 * *$ \\
\hline
\end{tabular}

**,* Sırasıyla 0.01 ve 0.05 düzeyinde önemlidir. Aynı harfle gösterilen değerler 0.05 önem düzeyinde farklı değildir.

\section{Sonuç ve Öneriler}

$\mathrm{Bu}$ çalışma, Bolu ekolojik şartları altında araştırma enstitüleri ve özel sektör tohumculuk firmaları tarafından farklı yıllarda tescil edilmiş 18 adet ekmeklik buğday çeşidinin yağışa dayalı şartlar altında tane verimi, verim unsurları ve kalite özelliklerinin belirlenmesi amacıyla yürütülmüştür. Denemede incelenen özelliklerin tane verimini ve kalite özelliklerini belirlemede önemli etkilere sahip oldukları anlaşılmaktadır. Bolu şartlarında yüksek verim ve kalite açısından ön plana çıkan Lucilla, Rumeli ve Aslı çeşitlerinin üretilmesi uygun olacaktır. Ancak, üstün kalite değerlerine sahip olmalarından dolayı Esperia ve Aldane çeşitleri un sanayinde kullanılabilecekleri uygun olacaktır.

\section{Kaynaklar}

Aktaş, H., Erdemci, I.., Karaman, M., Kendal, E., Tekdal, S. 2017. Bazı kışlık ekmeklik buğday genotiplerinin tane verimi ve bazı kalite özellikleri bakımından GGE biplot analizi yöntemi ile değerlendirilmesi. Türk Doğa ve Fen Dergisi, 6(1): 43-51.

Anonim, 2017. Türkiye İstatistik Kurumu. http://www.tuik.gov.tr (Erişim tarihi: 15 Eylül 2017).

Anonim, 2018. Bolu Meteoroloji il Müdürlüğü.

Aydoğan, S., Soylu, S. 2017. Ekmeklik buğday çeşitlerinin verim ve verim öğeleri ile bazı kalite özelliklerinin belirlenmesi. Tarla Bitkileri Merkez Araştırma Enstitüsü Dergisi, 26(1): 24-30.

Bayram, S., Öztürk, A., Aydın, M. 2017. Ekmeklik buğday genotiplerinin Erzurum koşullarında tane verimi ve verim unsurları yönünden değerlendirilmesi. Yüzüncü Yıl Üniversitesi, Tarım Bilimleri Dergisi, 27(4): 569-579.

Doğan, Y., Kendal, E. 2012. Ekmeklik buğday (Triticum aestivum L.) genotiplerinin tane verimi ve kalite özelliklerinin belirlenmesi. Gaziosmanpaşa Üniversitesi Ziraat Fakültesi Dergisi, 29(1): 113-121. 
Doğan, Y., Kendal, E. 2013. Diyarbakır koşullarında bazı ekmeklik buğday (Triticum aestivum L.) genotiplerinin tane verimi ve bazı kalite özelliklerinin belirlenmesi. Yüzüncü Yıl Üniversitesi Tarım Bilimleri Dergisi, 23(3): 199-208.

Doğan, Y., Toğay, Y., Toğay, N. 2014. Türkiye'de tescil edilmiş bazı ekmeklik buğday (Triticum aestivum L.) çeşitlerinin Mardin-Kızıltepe koşullarında verim ve bazı verim özelliklerinin belirlenmesi. Yüzüncü Yıl Üniversitesi Tarım Bilimleri Dergisi, 24(3): 241-247.

Erdoğan, E. 2018. Amik Ovası koşullarında bazı ekmeklik buğday (Triticum aestivum L.) genotiplerinin fizyolojik, morfolojik ve kalite özelliklerinin belirlenmesi. Hatay Mustafa Kemal Üniversitesi, Fen Bilimleri Enstitüsü, Tarla Bitkileri Anabilim Dalı Yüksek Lisans Tezi, s.55, Hatay.

Güçlü, A. 2015. Hatay ekolojik koşullarında bazı ekmeklik buğday (Triticum aestivum L.) genotiplerinin verim ve kalite özelliklerinin belirlenmesi. Mustafa Kemal Üniversitesi, Fen Bilimleri Enstitüsü, Tarla Bitkileri Anabilim Dalı Yüksek Lisans Tezi, s.77, Hatay.

JMP, 2010. JMP User Guide, Release 10 Copyright (C) 2010, SAS Institute Inc., Cary, NC, USA, ISBN 978-1-59994-408-1.

Kara, R., Dalkılıç, A.Y., Gezginç, H., Yılmaz, M.F., 2016. Kahramanmaraş koşullarında bazı ekmeklik buğday çeşitlerinin verim ve verim unsurları yönünden değerlendirilmesi. Türk Tarım ve Doğa Bilimleri Dergisi, 3(2): 172183.

Kendal, E. 2013. Yazlık ekmeklik buğday genotiplerinin Diyarbakır koşullarında verim ve kalite yönünden değerlendirilmesi. KSÜ Doğa Bilimleri Dergisi, 16(3): 16-24.

Kızılaslan, H. 2004. Dünya'da ve Türkiye'de buğday üretimi ve uygulanan politikaların karşılaştırılması. Gaziosmanpaşa Üniversitesi Ziraat Fakültesi Dergisi, 21(2), 23-38.

Kızılgeçi, F., Tazebay, N., Namlı, M., Albayrak, Ö. Yıldırım, M. 2017. The drought effect on seed germination and seedling growth in bread wheat (Triticum aestivum L.). International Journal of Agriculture, Environment and Food Sciences, 1: 33-37.

Kirby, E.J.M. 1988. Analysis of leaf, stem and ear growth in wheat from terminal spikelet stage to anthesis. Field Crops Research, 18: 127-140.

Kurt, Ö., Yağdı, K. 2013. Bazı ileri ekmeklik buğday (Triticum aestivum L.) hatlarının Bursa koşullarında verim özellikleri yönünden performansının araştırılması. U.Ü. Ziraat Fakültesi Dergisi, 2013(2): 19-31.

Mut, Z., Erbaş Köse, Ö., Akay, H. 2017. Bazı ekmeklik buğday (Triticum aestivum L.) çeşitlerinin tane verimi ve kalite özelliklerinin belirlenmesi. Anadolu Tarım Bilimleri Dergisi, 32: 85-95.

Özen, S., Akman, Z. 2015. Yozgat ekolojik koşullarında bazı ekmeklik buğday çeşitlerinin verim ve kalite özelliklerinin belirlenmesi. Süleyman Demirel Üniversitesi Ziraat Fakültesi Dergisi, 10(1): 35-43.

Sakin, M.A., Naneli, İ., Göy, A.G., Özdemir, K. 2015. Bazı ekmeklik buğday (Triticum aestivum L.) çeşitlerinin Tokat-Zile koşullarında verim ve verim komponentlerinin belirlenmesi. Gaziosmanpaşa Üniversitesi Ziraat Fakültesi Dergisi, 32(3): 119-132.

Sakin, M.A., Naneli, ì., İsmailoğlu, A.Y. ve Özdemir, K. 2017. Tokat Kazova koşullarında bazı ekmeklik buğday (Triticum aestivum L.) çeşitlerinin kuru ve sulu şartlarda verim ile kalite özelliklerinin belirlenmesi. Gaziosmanpaşa Üniversitesi Ziraat Fakültesi Dergisi, 34(Ek sayı): 87-96.

Tiryakioğlu, M., Demirtaş, B., Tutar, H. 2017. Türkiye'deki buğday veriminin karşılaştırılması: Hatay ve Şanlıurfa illeri örneği. Süleyman Demirel Üniversitesi Ziraat Fakültesi Dergisi, 12 (1):56-67.

Wiegand, C.L., Gebermann, A.H., Cuellar, J.A. 1981. Development and yield of hard red winter wheats under semitropical conditions. Agronomy Journal, 73(1): 29-37. 